\title{
Distribution and elevated soil pools of mercury in an acidic subtropical forest of southwestern China
}

\author{
Jun Zhou ${ }^{\text {a, b }}$, Zhangwei Wang ${ }^{\text {a, * }}$, Xiaoshan Zhang a, Jian Chen ${ }^{\text {a, b }}$ \\ ${ }^{a}$ Research Center for Eco-Environmental Sciences, Chinese Academy of Sciences, Beijing 100085, China \\ ${ }^{\mathrm{b}}$ University of Chinese Academy of Sciences, Beijing 100049, China
}

\section{A R T I C L E I N F O}

\section{Article history:}

Received 16 December 2014

Received in revised form

4 March 2015

Accepted 10 March 2015

Available online 30 March 2015

\section{Keywords:}

Soil mercury pool

Stream water

Soil solution

Soil/air exchange flux

\begin{abstract}
A B S T R A C T
Tieshanping catchment in southwest China was supposed to a large pool of atmospheric mercury. This work was aimed to examine $\mathrm{THg}$ (total mercury) concentrations, pools and influence factors in the acidic forest. THg concentrations were highly elevated in the study area, which was significantly depended on TOM (total organic matter) concentrations and altitudinal elevation, whereas negatively correlated with soil $\mathrm{pH}$. The pools of mercury accumulated in soils were correlated strongly with the stocks of TOM and altitude, ranged from 5.9 to $32 \mathrm{mg} \mathrm{m}^{-2}$ and averaged $14.5 \mathrm{mg} \mathrm{m}^{-2}$, indicating that the acidic forest was a great sink of atmospheric mercury in southwest China. THg concentrations in stream waters decreased with altitude increasing and regression analyses showed that soil/air exchange flux would be increased with the decrease of altitude. Present results suggest that elevation increasing decreases THg losses as low THg concentrations in runoffs and volatilization from soils.
\end{abstract}

๑) 2015 Elsevier Ltd. All rights reserved.

\section{Introduction}

Mercury is a highly toxic heavy metal and is well-known global contaminant that can affect the health of people and ecosystems (Depew et al., 2013; Li et al., 2013). Unlike other heavy metals, mercury can be emitted to the atmosphere in vapor form by both natural and anthropogenic sources. Archives of historical mercury deposition recorded from peat bog and lake sediments have provided evidence that elevated mercury deposition over the past century is directly related to the emissions of human industrial activities (Zhou et al., 2013; Liu et al., 2003). Studies in southwestern China, have estimated litterfall to be surpassing precipitation and throughfall and responsible for close to $70 \%$ of the mercury flux to a forested watershed, indicated that litterfall play a crucial role in mercury cycling in forest ecosystems (Fu et al., 2010b; Zhou et al., 2013).

Soils of forested watershed is a large reservoir of atmospherically deposited mercury, accounting for up to $90 \%$ of mercury in forests, which is predominantly bound with soil total organic matter (TOM) and more than $95 \%$ of the mercury resides in the organic soil (Grigal, 2003; Juillerat et al., 2012). Average

\footnotetext{
* Corresponding author.

E-mail address: wangzhw@rcees.ac.cn (Z. Wang).
}

concentrations of mercury in the surface levels of forest soils in remote areas reported by recent studies were much higher than a few decades ago (Zhou et al., 2013; Wang et al., 2013; Jin, 1993). However, by contrast, the data reported in the 1990s of Europe much higher than that in the 2000s (Schwesig et al., 1999; FOREGS, 2005; Szopka et al., 2011).

China is the largest developing country worldwide. With the rapid economic development during the past three decades, the amount of mercury emitted in China has increased significantly. Previous studies demonstrated that the concentration of total gaseous mercury (TGM) is elevated in the urban and suburban areas in Chongqing due to regional industrial and coal combustion emissions (Yang et al., 2009). Our previous studies demonstrated that atmospheric deposition was significantly elevated in Tieshanping National Forest Park (TNFP) area (Wang et al., 2009), which was several or even dozens of times compared to estimates obtained in North America and Europe (Johnson and Haines, 2007; Larssen et al., 2008). Therefore, it can be deduced that the subtropical forest in TNFP has become a massive atmospheric mercury sink. In this paper, we present a study on the mercury pools and effective factors of distribution in an upland forest located in the TNFP forested catchment. From January to November 2014, we undertook comprehensive field measurements on the distribution of mercury in litter, soils, soil solutions, stream water and air/soil fluxes. The main objective of this study was: (1) to examine the 
concentrations and pools of $\mathrm{THg}$ accumulated in soils, and their dependence on soil properties and altitude; and (2) to investigate the mercury output by stream water and soil/air flux influence on THg accumulation in different altitudes at the catchment.

\section{Materials and methods}

\subsection{Study area}

Tieshanping National Forest Park $\left(29^{\circ} 38^{\prime} \mathrm{N}, 104^{\circ} 41^{\prime} \mathrm{E}\right)$, one of the Sino-Norwegian multidisciplinary Integrated Monitoring Program on Acidification of Chinese Terrestrial Systems (IMPACTS) project monitoring sites, is located on a sandstone ridge, $20 \mathrm{~km}$ in the northeast of the metropolitan Chongqing City and on the side of the Yangtze River. The forest stand in TNFP is a Masson Pine dominated, coniferous-broad leave mixed subtropical forest and trees were planted in the 1960s (Wang et al., 2009). The soil is typically mountain yellow earth and its texture is haplic acrisol/alisol, which is severely acidified with an acidic pH 3.79 and TOM $12.7 \%$ in the organic horizon (Table 1 ).

\subsection{THg in litter and soils}

Litter and soil samples were collected at 66 sites inside the park and surrounding forest (Fig. 1) in March, 2014. Sampling sites represented various altitudes in the range $200-600 \mathrm{~m}$ a.s.l. In each sampling site, representative samples were collected in triplicates from the litter (ectohumus, 1-4 cm) and from the correspondingly organic layers (unequal depth, $2-4 \mathrm{~cm}$ ) and mineral topsoil layers $(4 \mathrm{~cm})$, which were collected within a $2 \mathrm{~m} \times 2 \mathrm{~m}$ plot and mixed together. Litter samples were stored into paper bags, and soils into a polyethylene zip-type bags. The sampling sites were chosen randomly and located at least $100 \mathrm{~m}$ away from roads and buildings. Soil samples were air-dried in a clean environment and litter samples dried at $60{ }^{\circ} \mathrm{C}$ by an oven. Subsequently, plant samples from each site were completely ground to a fine powder in a precleaned stainless steel blender and the air-dried soil samples were homogenized to a size of 150 meshes per inch with a mortar before chemical analysis.

A DMA-80 direct mercury analyzer (Milestone Ltd., Italy) was used for measuring THg concentrations in plant and soil samples. Instrument detection limit for $\mathrm{THg}$ was $0.005 \mathrm{ng}$ and the method detection limit was $0.34 \mathrm{ng} \mathrm{g}^{-1}$. Each sample was measured in duplicate and analyses were repeated when the coefficient of variability of samples exceeded 5\%. Quality assurance and quality control of the analytical processes were addressed with blind duplicates, matrix spikes, and certified reference materials. Instrument calibration curves covering the appropriate concentrations were confirmed by soil standards (IGGE IRMA China, $590 \pm 80 \mathrm{ng} \mathrm{g}^{-1}$ ) and citrus leaf standards (GBW10020, $150 \pm 20 \mathrm{ng} \mathrm{g}^{-1}$ ), and checked by the control standard samples every six samples. The precisions, obtained from ten duplicated measurements of samples, were $3.5 \%$ for soil and $5.7 \%$ for plant. An average THg concentration of $596 \pm 28 \mathrm{ng} \mathrm{g}^{-1}$ was obtained from IGGE IRMA and $148 \pm 7 \mathrm{ng} \mathrm{g}^{-1}$ citrus leaf.

\section{3. $\mathrm{THg}$ in stream water and soil solution}

Stream water samples were collected in the study area at the same time with soil (Fig. 1). The soil solution was sampled by tension lysimeters using ceramic suction cups (type P80, Staatliche Porzellan-Manufactur, Berlin) which were installed more than two years, repeatedly at $5 \mathrm{~cm}$ (L1) and $25 \mathrm{~cm}$ (L2) depth in the soil of 4 sites (A-D) along a hill slope in the forest. Site A was located on the top of slope; site B was in the middle; site $C$ was in the low-lying land and site D was in the wetland. All the water samples were poured into rigorously pre-cleaned $350 \mathrm{ml}$ PET bottles. For sample collection, bottles were rinsed three times with the water samples before being filled and preserved by adding trace-metal grade $\mathrm{HCl}$ (to $0.5 \%$ of total sample volume). Polyethylene gloves were used throughout the whole sampling campaign. PET bottles with samples were individually sealed into double successive polyethylene bags and packed in black plastic bags to avoid light, then shipped to the laboratory and frozen until analysis.

$\mathrm{THg}$ concentrations in water samples were determined following US EPA Method 1631 (US EPA, 1999). Samples were analyzed via $\mathrm{BrCl}$ oxidation followed by $\mathrm{SnCl}_{2}$ reduction, and dual amalgamation combined with CVAFS detector. The spike recoveries for $\mathrm{THg}$ were in the range of $97-110 \%$.

\subsection{Evasion flux of mercury from soil}

The soil/air mercury fluxes from forest soil were determined by using a coupling method of dynamic flux chamber and manual pure gold quartz trap. A semi-cylinder and open-bottom flux chamber made of quartz glass, which designed according to Fu et al. (2008), had been used throughout the sampling campaign. At the outlet of the chamber, an orifice was connected to two exits, one was connected a regulated suction pump, whereas the other exit was connected to a gold trap for trapping outlet TGM. On the two opposite section of the chamber, out of the inlet, another gold trap was placed to trap inlet TGM in the surrounding air.

Table 1

The effect of altitudinal zone on the mean concentrations of THg and soil parameters in various layers, and on the mean pools of THg and TOM.

\begin{tabular}{|c|c|c|c|c|c|c|c|c|}
\hline \multirow[t]{2}{*}{ Layer (depth) } & \multirow[t]{2}{*}{ Altitude (m) } & \multirow[t]{2}{*}{$\mathrm{pH}$} & \multirow[t]{2}{*}{ TOM (\%) } & \multicolumn{2}{|c|}{$\mathrm{THg}\left(\mathrm{ng} \mathrm{g}^{-1}\right)$} & \multirow[t]{2}{*}{ TOM pool $\left(\mathrm{g} \mathrm{m}^{-2}\right)$} & \multicolumn{2}{|c|}{$\mathrm{THg}$ pool $\left(\mathrm{mg} \mathrm{m}^{-2}\right)$} \\
\hline & & & & Range & Mean \pm SD & & Range & Mean \pm SD \\
\hline \multirow[t]{4}{*}{ Organic $(2-4 \mathrm{~cm})$} & $200-400$ & $3.9 \pm 0.21 \mathrm{ab}$ & $11 \pm 2.8 c$ & $54-263$ & $167 \pm 54 b c$ & $5.1 \pm 0.34 a$ & $3.5-10$ & $8.1 \pm 2.1 \mathrm{a}$ \\
\hline & $400-500$ & $3.8 \pm 0.12 c$ & $13 \pm 4.2 b c$ & $83-371$ & $181 \pm 57 \mathrm{abc}$ & $5.2 \pm 0.35 a$ & $5.2-12$ & $7.8 \pm 1.5 \mathrm{ab}$ \\
\hline & $500-600$ & $3.8 \pm 0.17 c$ & $14 \pm 4.7 b$ & $144-462$ & $224 \pm 75 a$ & $5.4 \pm 0.19 a$ & $6.0-24$ & $8.9 \pm 3.9 a$ \\
\hline & Avg. & $3.8 \pm 0.16 b c$ & $13 \pm 4.3 b c$ & $54-462$ & $191 \pm 65 a b$ & $5.3 \pm 0.31 a$ & $3.5-24$ & $8.2 \pm 2.6 a$ \\
\hline \multirow[t]{4}{*}{ Mineral top $(4 \mathrm{~cm})$} & $200-400$ & $4.0 \pm 0.11 a$ & $4.1 \pm 1.0 \mathrm{~d}$ & $23-99$ & $65 \pm 24 \mathrm{e}$ & $3.2 \pm 0.54 b$ & $2.0-7.6$ & $5.1 \pm 1.7 c$ \\
\hline & $400-500$ & $3.9 \pm 0.09 \mathrm{ab}$ & $4.7 \pm 0.72 d$ & $37-159$ & $73 \pm 26 \mathrm{de}$ & $3.6 \pm 0.36 b$ & $2.9-11$ & $5.5 \pm 1.8 \mathrm{c}$ \\
\hline & $500-600$ & $3.9 \pm 0.10 \mathrm{ab}$ & $5.4 \pm 1.2 d$ & $50-160$ & $101 \pm 30 d$ & $3.9 \pm 0.53 b$ & $4.1-12$ & $7.3 \pm 2.1 c$ \\
\hline & Avg. & $3.9 \pm 0.11 a$ & $4.8 \pm 1.0 \mathrm{~d}$ & $23-160$ & $80 \pm 31 \mathrm{de}$ & $3.6 \pm 0.50 b$ & $2.0-12$ & $6.0 \pm 2.1 c$ \\
\hline \multirow[t]{4}{*}{ Litter $(1-4 \mathrm{~cm})$} & $200-400$ & & $87 \pm 2.7 a$ & $110-180$ & $150 \pm 21 c$ & $2.3 \pm 0.14 c$ & $0.30-0.48$ & $0.39 \pm 0.050 d$ \\
\hline & $400-500$ & & $86 \pm 5.1 a$ & $109-208$ & $157 \pm 23 b c$ & $2.3 \pm 0.25 c$ & $0.31-0.51$ & $0.41 \pm 0.050 \mathrm{~d}$ \\
\hline & $500-600$ & & $85 \pm 5.8 a$ & $113-201$ & $160 \pm 26 b c$ & $2.2 \pm 0.29 c$ & $0.31-0.49$ & $0.41 \pm 0.060 d$ \\
\hline & Avg. & & $86 \pm 5.0 a$ & $109-208$ & $157 \pm 24 b c$ & $0.77 \pm 0.080 c$ & $0.30-0.51$ & $0.14 \pm 0.020 d$ \\
\hline All & Avg. & & & & & $9.4 \pm 0.32$ & $5.90-32$ & $15 \pm 3.9$ \\
\hline
\end{tabular}

Mean values for zones marked with different letters differ significantly (ANOVA, Tukey test, $\mathrm{P}=0.05$ ). 


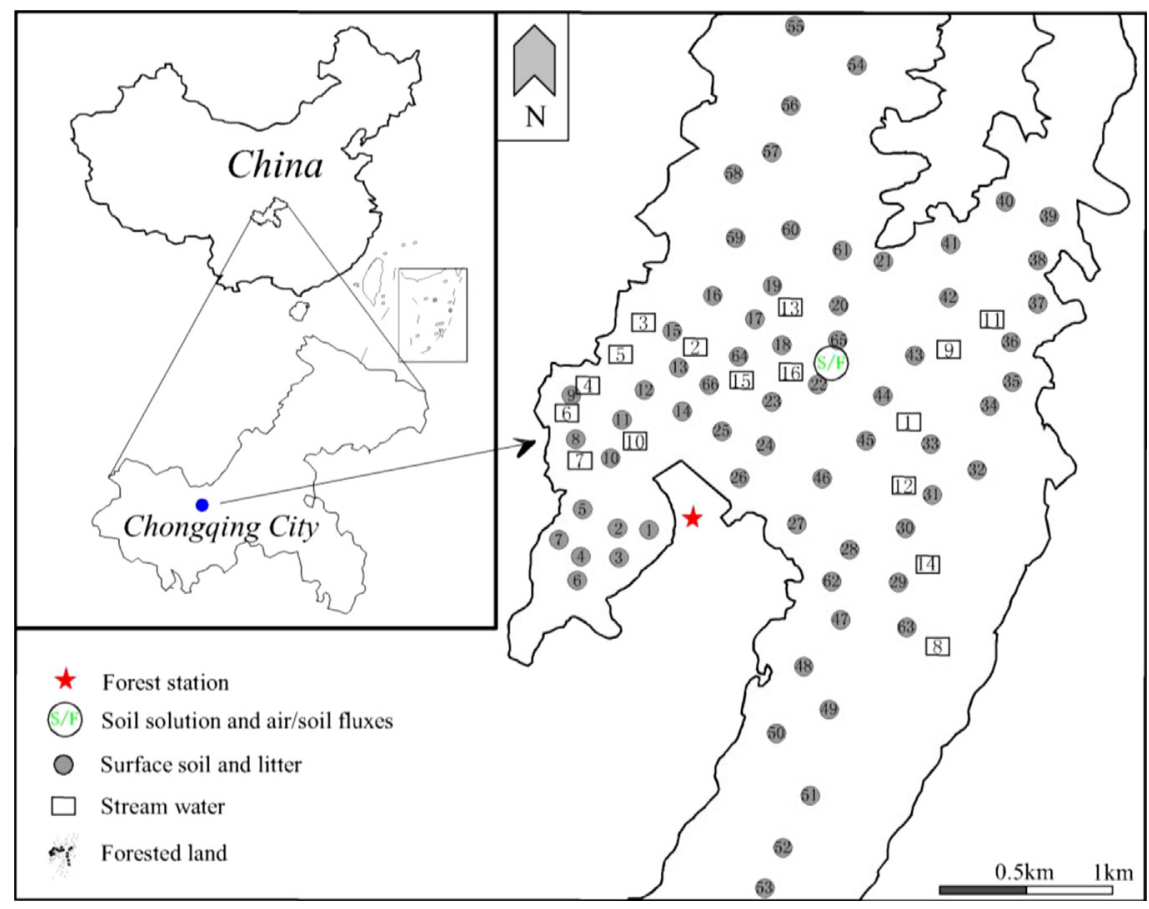

Fig. 1. The location of the study site.

To detect the collection efficiency of our gold quartz traps before sampling in field, two traps were connected in sequence and ambient lab air was sampled for $24 \mathrm{~h}$. Sampling flow rate was maintained $0.4-0.5 \mathrm{~L} \mathrm{~min}^{-1}$ by a rotameter and the air volume passing through each trap was accurately measured by a integrating flow meter. For all the traps, there was a small quantity of detectable mercury on the second traps (penetration $<1.0 \%$ ), which can be ignored. The mercury flux was calculated using the following equation:

$F=\left(C_{0}-C_{i}\right) \times Q / A$

where $F$ is the mercury flux ( $\mathrm{ng} \mathrm{m}^{-2} \mathrm{~h}^{-1}$ ); $C_{o}$ and $C_{i}$ are the steady state mercury concentration $\left(\mathrm{ng} \mathrm{m}^{-3}\right)$ of the outlet and inlet air stream, respectively; $A$ is the surface area $\left(0.06 \mathrm{~m}^{2}\right)$ enclosed by the chamber; $Q$ is the flushing flow rate $\left(10 \mathrm{~L} \mathrm{~min}^{-1}\right)$. In this work, mercury fluxes were measured from soils at two different altitudes (220 $\mathrm{m}$ and $512 \mathrm{~m}$ ) through semi-in situ experiment. One of the soils (including litterfall) was shipped up from lower elevations (220 $\mathrm{m}$ a.s.l) to the higher elevations (512 $\mathrm{m}$ a.s.l), and replaced the original surface soil about $10 \mathrm{~cm}$. The other one was the undisturbed soil in $512 \mathrm{~m}$ a.s.l. The shipped soil was equilibrated for one month before the measurement of flux by two chambers side by side simultaneously. The fluxes were continuous monitoring for a week, including gold traps were sampled every half an hour for 1 day $(24 \mathrm{~h})$ and collected at 8:00 am and 6:00 pm in the remaining 6 days, represented daytime and night, respectively. All the gold traps were brought back to TNFP Forestry Station for mercury quantification by CVAFS detector (Brooks Rand III, US EPA, 1999) using dual gold trap amalgamation procedure after every sampling.

\subsection{THg pools, soil $\mathrm{pH}$ and TOM}

Soil $\mathrm{pH}$ was measured with a glass electrode $\mathrm{pH}$ meter in a 1:5 soil: water suspension. TOM content in forest soils and litter were determined by using the sequential loss on ignition (LOI) (Heiri et al., 2001; Fu et al., 2010a, b; Zhou et al., 2013). Air-dried soil samples (WS) were dried at $105^{\circ} \mathrm{C}$ by an oven for about $12-24 \mathrm{~h}$ to obtain the dry weight of the samples $\left(\mathrm{DW}_{105}\right)$. The heated dry sample was then burned at $550{ }^{\circ} \mathrm{C}$ for $4 \mathrm{~h}$ to obtain the $\mathrm{DW}_{550}$. Then, the TOM content ( $\left.\mathrm{LOI}_{550}\right)$ was calculated according to the following formula (2):

$\mathrm{LOI}_{550}=100\left(\mathrm{DW}_{105}-\mathrm{DW}_{550}\right) / \mathrm{WS}$

On the basis of measured mercury and TOM concentrations in the three layers, the pools of mercury and TOM accumulated in soil were calculated for each sampling site on the soil bulk density $\left(\rho_{i}\right)$ and concentrations $\left(c_{\mathrm{i}}\right)$ according to the method of Zhou et al. (2013) as the following formula:

$\mathrm{M}_{\mathrm{THg} / \mathrm{TOM}}=\sum_{i=1}^{n} c_{\mathrm{i}} \times \rho_{\mathrm{i}}=\sum_{i=1}^{n} c_{\mathrm{i}} \times s_{\mathrm{i}} / v_{\mathrm{i}}$

Part of samples collected by a cutting ring sampler, and $v_{i}$ was the known volume of the cutting ring sampler and $s_{i}$ was the constant weight of the samples dried in an oven at $105^{\circ} \mathrm{C}$. For this purpose, some other soil bulk density was assessed by the model proposed by Prevost (2004).

\section{Results and discussion}

\subsection{THg concentrations in litter and soils}

The concentrations of $\mathrm{THg}$ in the layers of litter and surface soils in the TNFP, varied in a broad range: $23-462 \mathrm{ng} \mathrm{g}^{-1}$ (Table 1). High values of standard deviation (SD) and variability coefficient proved a high diversity of $\mathrm{THg}$ concentrations, particularly in the organic soil layers. Higher $\mathrm{THg}$ concentrations in the organic layer compared to forest litter result partly from natural processes of litterfall decomposition and transformation, in which organic matter binding mercury compounds are usually more stabilized via complexing, humification and adsorption to clay minerals (Schlüter, 2000; Gunda and Scanlon, 2013). This result was 
consistent well with observations reported by other studies which stressed the affinity of atmospheric mercury to accumulate in the surface layers of soils (Wang et al., 2013; Pena-Rodriguez et al., 2014).

Generally, THg concentrations in surface soils in the TNFP were comparable to mercury levels from other forest soils in China (Lin et al., 2012; Fu et al., 2010a; Liu et al., 2003). But THg concentrations in the soils of our study area were slight lower than THg levels from some remote areas of Eastern Europe which were generally more than $200 \mathrm{ng} \mathrm{g}^{-1}$ for organic layers, primarily due to much higher atmospheric deposition to the forest (Szopka et al., 2011; Gunda and Scanlon, 2013; Navrátil et al., 2014). However, THg concentrations in surface soils and litter in the study area were much higher (1.5-2.0 folders higher) than those observed in mountain areas of North America and northeastern China, which were generally less than $150 \mathrm{ng} \mathrm{g}^{-1}$ for surface soils and $100 \mathrm{ng} \mathrm{g}^{-1}$ for litterfall (Larssen et al., 2008; Juillerat et al., 2012; Tabatchnick, 2012; Luo et al., 2014). We may attribute the elevated concentrations in litter and soils to the elevated TGM concentrations (3.8 $\mathrm{ng} \mathrm{m}^{-3}$ in March, our unpublished data) in ambient air in the study area, which was from regional industrial and coal combustion emissions (Yang et al., 2009) and given rise to high THg in foliage and throughfall and resulted in elevated loading of THg in the study forest.

Basic physical and chemical characteristics of soil, especially TOM and $\mathrm{pH}$, play the most important role in regulating soil mercury concentration and transformation. Enrichment in mercury observed in the litter layer and organic layer compared with mineral topsoil layer, undoubtedly demonstrates the crucial role of TOM in the accumulation of air-borne mercury. Regression analysis based on Pearson correlation coefficient, indicated that the concentrations of $\mathrm{THg}$ in the organic and mineral topsoil layers were linearly dependent on the content of TOM in soil (Fig. 2). Like other soft acid metal, mercury preferentially binds to ligands of sulfur, but the main form in which it accumulates in soils, is the compounds with TOM (Yang et al., 2007). Soil TOM and THg interact strongly with each other and the interactions can greatly influence the transport, transformation, and mobility (Grigal, 2003). Thus this physical-chemical bond helps stabilize mercury in the soil system and inhibits dissolution to the stream water (Schwesig et al., 1999) and volatilization into the atmosphere (Schlüter, 2000).

Changes in soil pH alter not only the fractions of mercury in soil solution but can also change mercury speciation in soils (Gunda and Scanlon, 2013). Higher $\mathrm{THg}$ concentrations but lower $\mathrm{pH}$ observed in the organic layer compared with mineral topsoil layer, undoubtedly indicated the crucial role of $\mathrm{pH}$ in the accumulation of mercury in soils. The scatterplot in the Fig. 2 illustrates the significantly negative relationships between $\mathrm{THg}$ and $\mathrm{pH}$ concentrations in both soil layers. As $\mathrm{pH}$ of the soil increases, more affinity of mercury binding groups in the organic matter is decreased, therefore more mercury is released from the soil (Gunda and Scanlon, 2013).

THg concentrations in three layers under different altitude are presented in Table 1. In general, the litter collected from TNFP was comparable in terms of leaf types, with Masson Pine varieties being the most dominant species. Litter mercury concentrations were not found to be significantly different and correlated with altitudes (Tables 1 and 2). This relatively homogenous distribution of mercury in litter is possibly due to TGM involved in leaf-level accumulation, while TGM may be well mixed and abundant in the atmosphere. Therefore litter mercury distribution varied a little with respect to aspect and litterfall mercury deposition was similar in the study area.

Interestingly, altitudinal distribution of mercury concentrations in the organic and mineral topsoil layer differed from those in the litter, which significantly correlated with altitude (Table 2). In previous studies, Zechmeister (1995) and Evans and Hutchinson (1996) have shown that surface soils at higher altitudes received higher annual precipitation, and simultaneously higher loadings of pollutants, including mercury. As well as the increasing of altitude reduced turnover rates in soil TOM pools and lower $\mathrm{pH}$, which allows a greater opportunity for mercury accumulation and suppression of mercury release from organic layers (Schlüter, 2000). Moreover, lower temperature at higher altitude also restrained mercury evasion from soils as discussed in section 3.3. For the mineral topsoil in the areas endangered by acid deposition, the $\mathrm{THg}$ content correlated with altitude and corresponding organic soil layers, probably because the level of $\mathrm{THg}$ concentrations and leaching of base constituents from organic soils was increased at higher altitudes due to higher precipitation and $\mathrm{THg}$ in organic soils. Therefore, the significant correlation of $\mathrm{THg}$ concentration with TOM and $\mathrm{pH}$ in organic and mineral topsoil (Fig. 2) demonstrated the relation of all these parameters to altitude or terrain influence. However, Fu et al. (2010a) and Mohammad et al. (2014) have found the opposite relationships, of which $\mathrm{THg}$ in surface soils and foliage decreased with altitudinal elevation.

\section{2. $\mathrm{THg}$ pools in litter and soils}

THg pools (down to mineral topsoil) in the TNFP subtropical forest remain in a broad range, from 5.9 to $32 \mathrm{mg} \mathrm{m}^{-2}$ and with the mean value of $14.5 \mathrm{mg} \mathrm{m}^{-2}$ (Table 1) and should be considered as relatively high compared with the values reported by other literature (Table 3). However, it should be stressed that the attempts to compare our results with the data from other studies are facing some difficulties, because the other studies either reported the amounts of $\mathrm{THg}$ accumulated in various horizons which were inconsistent with our research, or calculated THg pools accumulated within soil profiles of various depths. We have found that the largest amounts of THg were present in the organic layer (44-75\% of the total pool) due to significantly higher concentrations (Table 1). The contributions of THg present in forest litter were the lowest with mean of $2.8 \%$ and the remaining $41 \%$ was stored in the mineral topsoil layer (Fig. 3a). Additionally, we found the correlation coefficient of THg and TOM pools was particularly strong (Fig. 4a).

In order to assess the quantity ratio of THg to TOM pools, the mean values of $\mathrm{THg} / \mathrm{TOM}$ ratio were calculated for separate soil layers. The $\mathrm{THg} / \mathrm{TOM}$ ratio determined for the litter was in the range of $0.11-0.29 \mu \mathrm{g} \mathrm{g}^{-1}$ (mean $0.18 \mu \mathrm{g} \mathrm{g}^{-1}$ ) and corresponding values for the organic and mineral topsoil layers were $1.56 \mu \mathrm{g} \mathrm{g}^{-1}$

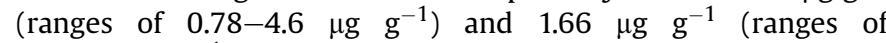
$0.83-43 \mu \mathrm{g} \mathrm{g}^{-1}$ ), respectively. Some studies reported much lower values of $\mathrm{THg} / \mathrm{OM}$ (approximate to $0.22 \mu \mathrm{g} \mathrm{g}^{-1}$ ) in organic horizons in North American and European forests of the last century (Låg and Steinnes, 1978). The data from central and eastern Europe and were higher, ranging from 0.70 to $0.90 \mu \mathrm{g} \mathrm{g}^{-1}$ (Godbold, 1994) and averaged $0.77 \mu \mathrm{g} \mathrm{g}^{-1}$ in top $10 \mathrm{~cm}$ soils (Szopka et al., 2011). Our results referring to the organic soil layer are almost 2-7-fold as high as those given by most authors. The reason may be related to ten to thirty times air-borne mercury input in our study areas compared forest areas of North America and Europe according our previous study (Wang et al., 2009).

The tendency of increasing THg concentrations in soils with growing altitudes as described above, was also reflected by the increase of $\mathrm{THg}$ pools accumulated in the corresponding layers down to the depth of mineral topsoil (Fig. 4b). The dependence was significant but much lower compared to the correlation between TOM with THg pools in soils and the results of a two-way factorial ANOVA analysis indicated that there were no significant differences 

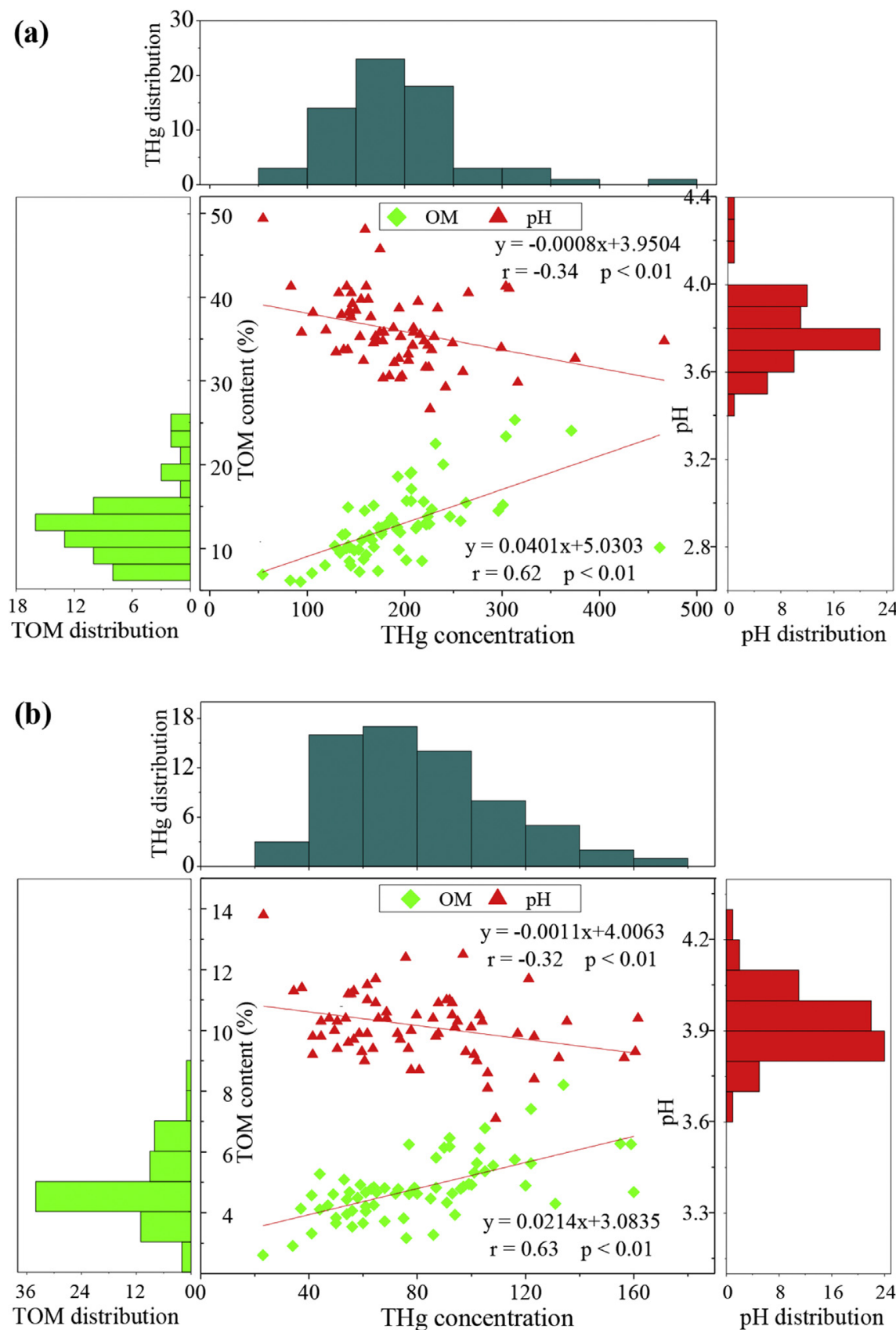

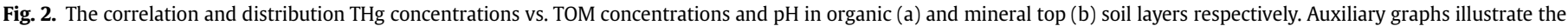
data distribution interval.

$(P>0.05)$ between the pools of mercury accumulated in soils in various altitudinal zones (Fig. 3b). A similar relationship also referred to the stocks of TOM which were significant enrichment with the increase of elevations (Table 2). It turns out that the pool of

Table 2

Correlation coefficients of Altitude (m a.s.l.) with soil THg and parameters in TNFP.

\begin{tabular}{llllcl}
\hline & $\mathrm{pH}$ & $\mathrm{TOM}$ & $\mathrm{THg}$ & $\mathrm{TOM}$ pool & THg pool \\
\hline Litter layer & & -0.070 & 0.050 & -0.070 & 0.020 \\
Organic layer & $-0.34^{\mathrm{a}}$ & $0.27^{\mathrm{b}}$ & $0.34^{\mathrm{a}}$ & $0.27^{\mathrm{b}}$ & 0.18 \\
Mineral topsoil layer & $-0.38^{\mathrm{a}}$ & $0.45^{\mathrm{a}}$ & $0.46^{\mathrm{a}}$ & $0.46^{\mathrm{a}}$ & $0.43^{\mathrm{a}}$ \\
Total layers & & & & $0.42^{\mathrm{a}}$ & $0.35^{\mathrm{a}}$ \\
\hline
\end{tabular}

${ }^{\text {a }}$ Correlation is significant at the 0.01 level (two-tailed).

b Correlation is significant at the 0.05 level (two-tailed). stored TOM is a key factor governing the amounts of THg accumulated in soils of the TNFP forest. Such dependence was corresponded with our inference, as severe environmental conditions at higher altitudes were supposed to receive higher mercury wet deposition and suppress organic matter decomposition to make for TOM and THg enrichment in the organic layer.

\subsection{Mercury in stream water and evasion from forest soil: possible} effects on mercury distribution in forest soils

Variation of un-filtered $\mathrm{THg}$ concentrations in stream water in the TNFP is shown in Fig. 5a. THg concentrations varied between 1.5 and $5.0 \mathrm{ng} \mathrm{L^{-1 }}$, with an overall average concentration of $3.1 \pm 1.2 \mathrm{ng} \mathrm{L}^{-1}$. THg concentrations in stream water were obviously 
Table 3

THg pools and output flux of THg in the study area and literature.

\begin{tabular}{|c|c|c|c|c|}
\hline \multirow[t]{2}{*}{ Site localities } & \multicolumn{2}{|l|}{ THg pools } & \multirow[t]{2}{*}{ Stream water concentrations $\left(\mathrm{ng} \mathrm{L}^{-1}\right.$ ) } & \multirow[t]{2}{*}{ References } \\
\hline & Depth $(\mathrm{cm})$, horizon & Pools, $\mathrm{mg} \mathrm{m}^{-2}$ & & \\
\hline Riparian wetland, USA & $0-90$ & 30 & & Selvendiran et al., 2008 \\
\hline Beaver meadow, USA & $0-90$ & 20 & & \\
\hline Upland, USA & $0-90$ & 64 & & \\
\hline Lehstenbach, Germany & $0-60$ & 89 & 13 & Schwesig and Matzner, 2000 \\
\hline Steinkreuz, Germany & $0-60$ & 19 & 10 & \\
\hline Five forests, Czech & Organic & $5.3-10$ & & Navrátil et al., 2014 \\
\hline Langtjern, Norway & $\mathrm{O}-\mathrm{B}$ & 17 & $4.0^{\mathrm{a}}$ & Larssen et al., 2008 \\
\hline Karkonosze, Polish-Czech & Litter to 20 & 17 & & Szopka et al., 2011 \\
\hline Marcell, USA & $0-50$ & 48 & 12.5 & Grigal et al., 2000 \\
\hline PANP young stand, Canada & Organic & 1.0 & & Friedli et al., 2007 \\
\hline PANP old stand, Canada & Organic & 2.9 & & \\
\hline Vermont, USA & A & 7.5 & & Juillerat et al., 2012 \\
\hline LGS, south China & $0-60$ & 109 & 4.3 & Wang et al., 2009 \\
\hline TNFP, southwest China & Litter to mineral topsoil & 15 & 3.1 & This study \\
\hline
\end{tabular}

a concentration was estimated from figures.

higher than those reported from some natural forest (Table 3), which was probable attributed to the great soil mercury sequestration. In addition, soil erosion and runoff were also important sources to stream water. Number of the sampling sites was increased with elevation and No 1 to 7 were under an altitude of $300 \mathrm{~m}$ a.s.l., which seems to be higher concentrations than that in high elevation areas (Fig. 5a). Linear regression analysis showed that altitude significantly negatively correlated with THg in stream waters $(r=-0.49, p<0.05)$. The reasons may be that, firstly, mercury in stream water was probably derived from increased soil erosion and volume of runoff during stream transport in lower altitude with larger slopes. Secondly, lower TOM content and pH in soils of low altitude areas increased THg loss. These, in turn, indicated that more mercury output by runoff led to low concentrations in soil at low altitudes. Therefore, this may be another reason of mercury concentrations and pools increased with the increase of elevations.

Concentrations of $\mathrm{THg}$ in the soil solution tended to increase with soil depth for the site A-C and decreased from top to down of the hill slope in the TNFP (Fig. 5b). However, in contrast, our
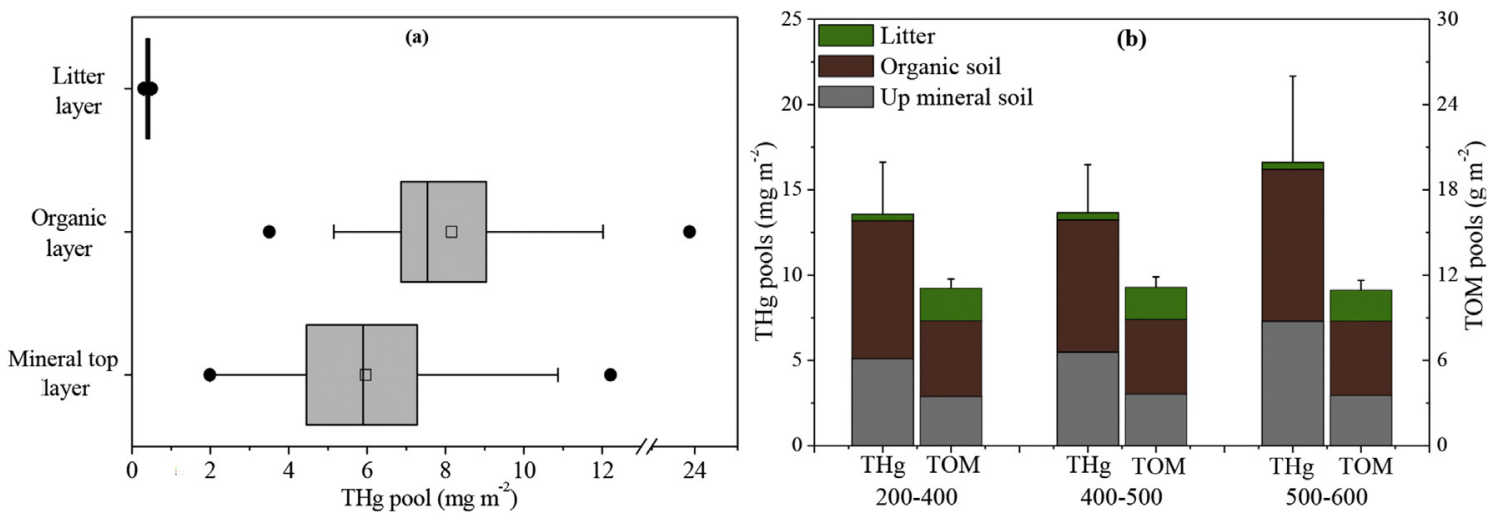

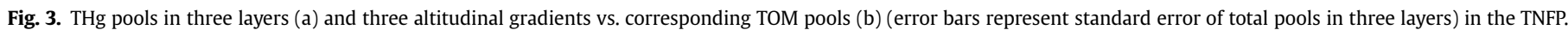
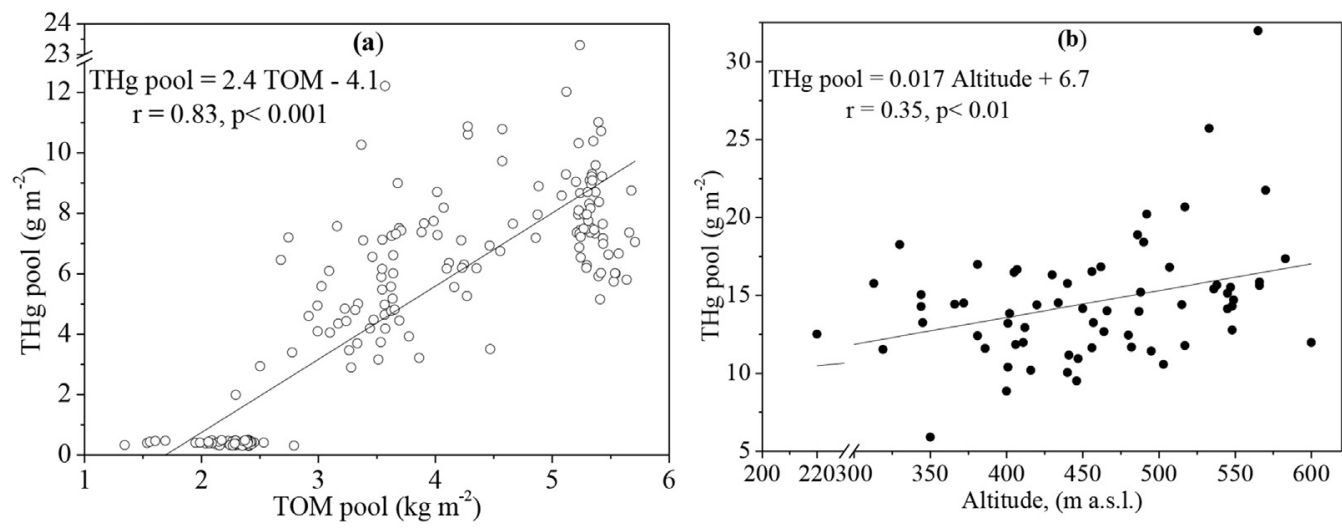

Fig. 4. Dependence of THg pools accumulated in soils on TOM pools for all soil samples (a) and altitude for all sampling sites (b). 

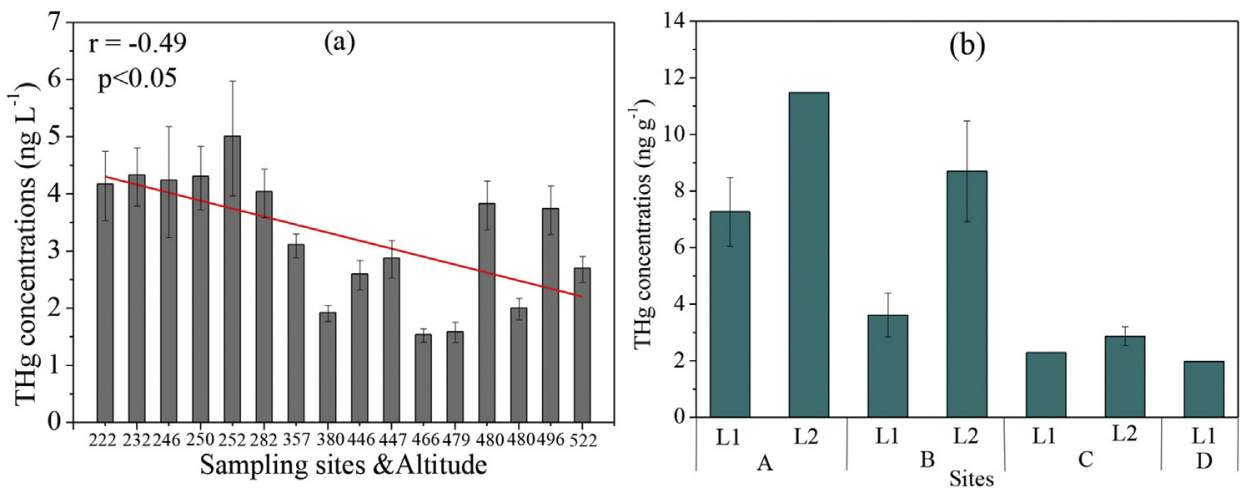

Fig. 5. Distribution of THg in stream waters (a) and soil solutions (b) in TNFP.

previous study (Wang et al., 2009) reported that concentrations of $\mathrm{THg}$ in the soil solution strongly decreased with increasing depth, which in top soils $\left(60 \pm 40 \mathrm{ng} \mathrm{L}^{-1}\right)$ were much higher than that in deep soils ( $\left.10.1 \pm 7.9 \mathrm{ng} \mathrm{L}^{-1}\right)$ and this phenomenon was also found by Rieder et al. (2014) in five Swiss forests. Thus it should be noted that our sampling was carried out during a heavy rain and the large amount of rainfall may dilute the $\mathrm{THg}$ concentrations in top soil solutions. Similarly, along with the hill slope, dilute strength was greater by surface runoff, thus result in highest THg in the soil solution on the top and lowest in the wetland. Significantly higher soil $\mathrm{THg}$ concentrations was observed in top soils compared to deep soils, but $\mathrm{THg}$ in soil solutions was the opposite, therefore, the question should be asked now, to what extent, THg deposited to the soil surface has been translocated or leached down to deep soils. Some authors reported high mobility of $\mathrm{THg}$ in acidic forest soils, attributed to the strong coupling of mercury to dissolved or colloidal organic matter (Akerblom et al., 2008). To our previous results, THg concentrations in deep soil solutions were comparable, but these in top soil were much lower. We may suppose that heavy rainfall in the acidic forest diluted $\mathrm{THg}$ concentration in surface soils but not deep ones and THg leaching amount from surface soils directly related to rainfall, even if we have not measured dissolved organic matter.

Mercury fluxes was obtained from 24 consecutive hours and 7 days of field sampling as shown in Fig. 6 and Fig. 7. Overall, all net evasions were observed during the sampling period, and the average fluxes of mercury emission was $6.3 \mathrm{ng} \mathrm{m}^{-2} \mathrm{~h}^{-1}$ for the soil collected from altitude $220 \mathrm{~m}$ and $6.4 \mathrm{ng} \mathrm{m}^{-2} \mathrm{~h}^{-1}$ for the soil in altitude $512 \mathrm{~m}$ during sampling time ( 7 days). Within natural forest ecosystems, soil/air exchange flux of mercury is an important

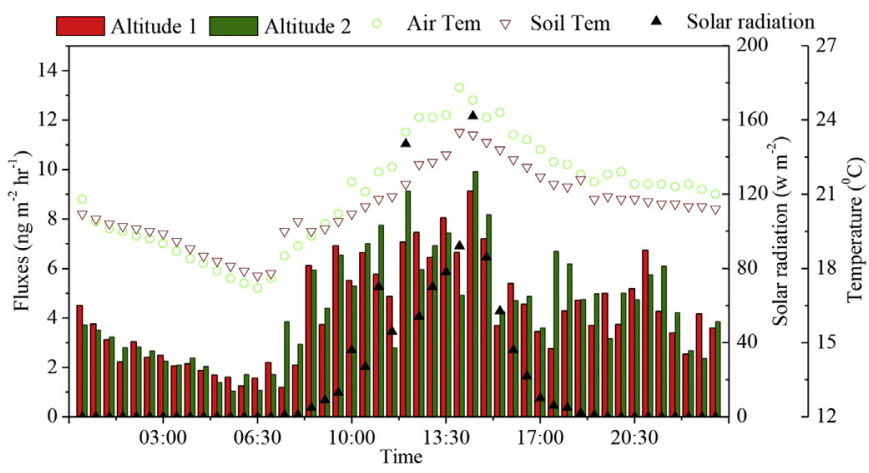

Fig. 6. Effect of ambient air and soil temperature and solar radiation on mercury emission fluxes of soils collected from Altitude $220 \mathrm{~m}$ (Altitude 1) and Altitude $512 \mathrm{~m}$ (Altitude 2). pathway for mercury deposition or losses from landscapes. However, it is still difficult to accurately quantify the magnitude of the emission of mercury from the study area because mercury emission from soil was controlled by multiple interacting factors, such as experimental methods (Eckley et al., 2010), soil physical-chemical factors (soil temperature and humidity, soil gas mercury, soil TOM, pH etc.) (Choi and Holsen, 2009; Yang et al., 2007) and meteorological parameters (e.g. UV radiation, air temperature, rainfall) (Gabriela et al., 2011; Corbett-Hains et al., 2012), etc. Diurnal variation trends of $24 \mathrm{~h}$ of mercury exchange flux are presented in Fig. 6, which showed a significant correlation with air temperature, soil temperature and solar radiation for both soils ( $p<0.01$ for all) and these observations round out the research results of many years (Ericksen et al., 2006; Fu et al., 2012; Mazur et al., 2014).

Altitude position is considered as a major soil forming factor (Jenny, 1941). In this study, the $\mathrm{pH}$ of surface organic soils and up mineral soils had a significant negative correlation with elevation (Table 2). This indicated stronger acidification at higher altitudes, probably owing to high precipitation and strong soil leaching. Instead, TOM was significant positive correlated with elevation in both soil layers (Table 2). Soils at lower altitude have higher $\mathrm{pH}$ and lower TOM, which was supposed to increase opportunity for mercury evasion. However, based on our continuous observation of 7 days, there was no obvious fluxes difference between the two kinds of soils (Fig. 6). Previous studies showed that soil/air mercury fluxes

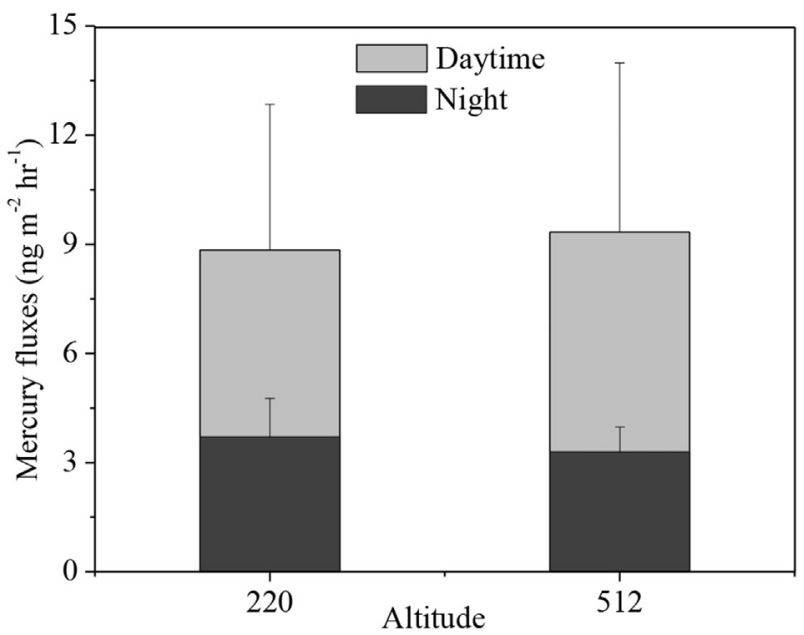

Fig. 7. Comparisons of mercury emission fluxes between soils collected from Altitude $220 \mathrm{~m}$ and Altitude $512 \mathrm{~m}$ for 7-day sampling. 

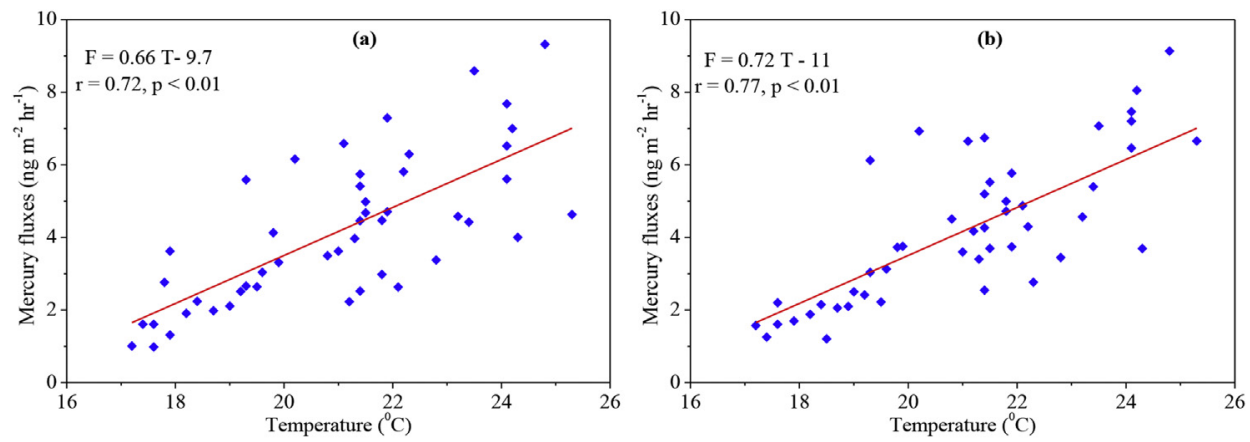

Fig. 8. Regression plots between temperature and mercury emission fluxes of soil collected from Altitude $220 \mathrm{~m}$ (a) and Altitude $512 \mathrm{~m}$ (b).

were significantly correlated with air temperature in subtropical forests in China (Fu et al., 2010a; Ma et al., 2013). Regression analyses also showed that mercury emission fluxes (F) of the two kinds of soils were statistically significant with air temperature $(\mathrm{T})$ in our studies $\left(\mathrm{F}_{220}=0.66 \mathrm{~T}-9.7, \mathrm{~F}_{512}=0.72 \mathrm{~T}-11, \mathrm{r}=0.72\right.$ and 0.77 , $\mathrm{p}<0.01$ for both, respectively) (Fig. 8a and b), which may imply that temperature can be used to predict the soil emission of mercury in the study area (Fu et al., 2010a). As the average temperature is $21^{\circ} \mathrm{C}$ in the $24 \mathrm{hr}$-sampling day, the corresponding fluxes are 4.2 and $4.1 \mathrm{ng} \mathrm{m}^{-2} \mathrm{~h}^{-1}$ calculated by linear equations, which was comparable with the directly measured value of 4.1 and 4.2 for the soils collected from Altitude $220 \mathrm{~m}$ and Altitude $512 \mathrm{~m}$, respectively. However, it is known as the altitude increases $100 \mathrm{~m}$, the temperature may gradually reduce $0.6{ }^{\circ} \mathrm{C}$. Thus, the temperature may be 22.8 at the elevation of $220 \mathrm{~m}$ and the corresponding flux is $5.4 \mathrm{ng} \mathrm{m}^{-2} \mathrm{~h}^{-1}$ calculated by linear equations. Evasion fluxes of the kinds of the soils was comparable at the same meteorological conditions and elevation, but if we considered the temperature affected by elevation, the fluxes would be increased in lower elevations. Therefore, this may be also an important reason for the soil mercury concentrations and pools distribution along with the altitude.

Therefore, the possible factor of effects on mercury distribution in this acidic forest soils primarily come from two aspects: input and output. Actually, we have not directly measured the input of mercury in various altitudes, but higher altitudes were supposed to receive higher mercury deposition (Zechmeister, 1995). However, we have directly measured $\mathrm{THg}$ in the stream water and soil evasion flux by a semi-in situ experiment in different altitudes, which were the two major output pathways from forest soil. The result indicated that the output by runoff and evasion flux were both higher at low altitude. Thus, our observation suggested that the characters of mercury distribution in the forest soil was driven primarily by higher mercury input and lower output at higher altitude.

\section{Conclusions}

Measurements of THg concentration and pool in litter, organic and mineral top soils were carried out at an acidic forest catchment in Tieshanping National Forest Park, southwest China. Soil emission flux, stream water and soil solutions were also investigated. Undoubtedly, Air-borne depositions are the main source of mercury in soils. The mean THg concentrations in litter, organic and mineral top soils were 157,191 and $80 \mathrm{ng} \mathrm{g}^{-1}$, respectively, which were strongly influence soil TOM and $\mathrm{pH}$, as well as altitude. THg pool from litter to mineral topsoil was $14.53 \mathrm{mg} \mathrm{m}^{-2}$, which were strongly dependent on the amounts of TOM stored. Pools of THg indicated that the acidic forest in southwest China was a great sink of atmospheric mercury. THg concentrations in stream waters and soil/air exchange flux of mercury would be increased along with the decrease of the altitude. Therefore, elevated mercury concentrations in runoffs and volatilization from soil were identified as the major pathway for increasing THg losses gradually along with the down of the elevation height.

\section{Acknowledgments}

This research was funded by the National Basic Research Program of China (No. 2013CB430002), "Strategic Priority Research Program" of the Chinese Academy of Sciences, Grant No. XDB14020205 and Natural Science Foundation of China (No. 41373124 and 41371461). The authors would like to thank Mingquan Zou for his assistance in field works. Two anonymous reviewers are acknowledged for providing insightful comments and suggestions.

\section{References}

Akerblom, S., Meili, M., Bringmark, L., Johansson, K., Kleja, D.B., Bergkvist, B., 2008. Partitioning of $\mathrm{Hg}$ between solid and dissolved organic matter in the humus layer of boreal forests. Water Air Soil Pollut. 189, 239-252.

Choi, H.D., Holsen, T.M., 2009. Gaseous mercury fluxes from the forest floor of the adirondacks. Environ. Pollut. 157, 592-600.

Corbett-Hains, H., Walters, N.E., Heyst, B.J.V., 2012. Evaluating the effects of subzero temperature cycling on mercury flux from soils. Atmos. Environ. 63, 102-108.

Depew, D.C., Burgess, N.M., Campbell, L.M., 2013. Modelling mercury concentrations in preyfish: derivation of a national-scale common indicator of dietary mercury exposure for piscivorous fish and wildlife. Environ. Pollut. 176, 234-243.

Eckley, C.S., Gustin, M., Lin, C.J., Li, X., Miller, M.B., 2010. The influence of dynamic chamber design and operating parameters on calculated surface-to-air mercury fluxes. Atmos. Environ. 44, 194-203.

Ericksen, J.A., Gustin, M.S., Xin, M., Weisberg, P.J., Fernadez, G.C.J., 2006. Air-soi exchange of mercury from background soils in the United States. Sci. Total Environ. 366, 851-863.

Evans, C.A. Hutchinson, T.C. 1996. Mercury accumulation in transplanted moss and lichens at high elevation sites in Quebec. Water Air \& Soil Pollut. 90, 475-488.

FOREGS, 2005. Geochemical Atlas of Europe. In: Salminen, R. (Ed.), Part 1 - Background Information, Methodology and Maps. European Geology Surveys. Geological Survey of Finland (Espoo).

Friedli, H.R., Radke, L.F., Payne, N.J., McRae, D.J., Lynham, T.J., Blake, T.W., 2007 Mercury in vegetation and organic soil at an upland boreal forest site in Prince Albert national park, Saskatchewan, Canada. J. Geophys. Res. 112, G01004.

Fu, X., Feng, X., Sommar, J., Wang, S., 2012. A review of studies on atmospheric mercury in China. Sci. Total Environ. 421, 73-81.

Fu, X.W., Feng, X., Zhu, W., Rothenberg, S., Yao, H., Zhang, H., 2010a. Elevated atmospheric deposition and dynamics of mercury in a remote upland forest of southwestern China. Environ. Pollut. 158, 2324-2333.

Fu, X.W., Feng, X.B., Dong, Z.Q., Yin, R.S., Wang, J.X., Yang, Z.R., Zhang, H., 2010b. Atmospheric gaseous elemental mercury (GEM) concentrations and wet and dry deposition of mercury at a high-altitude mountain peak in south China. Atmos. Chem. Phys. 10, 2425-2437.

Fu, X.W., Feng, X.B., Wang, S.F., 2008. Exchange fluxes of $\mathrm{Hg}$ between surfaces and atmosphere in the eastern flank of Mount Gongga, Sichuan province, southwestern China. J. Geophys. Res. 113, D20306. http://dx.doi.org/10.1029/ 2008JD009814. 
Gabriela, M.C., Williamson, D.G., Brooks, S., 2011. Potential impact of rainfall on the air-surface exchange of total gaseous mercury from two common urban ground surfaces. Atmos. Environ. 45, 1766-1774.

Godbold, D.L., 1994. Mercury in forest ecosystems, risk and research needs. In: Watras, C.J., Huckabee, J.W. (Eds.), Mercury Pollution: Integration and Synthesis Lewis Publ, Boca Raton, FL, pp. 295-303.

Grigal, D., Kolka, R., Fleck, J., Nater, E., 2000. Mercury budget of an upland-peatland watershed. Biogeochemistry 50, 95-109.

Grigal, D.F., 2003. Mercury sequestration in forests and peatlands: a review. J. Environ. Qual. 32, 393-405.

Gunda, T., Scanlon, T.M., 2013. Topographical influences on the spatial distribution of soil mercury at the catchment scale. Water Air \& Soil Pollut. 224,1511. http:/ dx.doi.org/10.1007/s11270-013-1511-7.

Heiri, O., Lotter, A.F., Lemcke, G., 2001. Loss on ignition as a method for estimating organic and carbonate content in sediments: reproducibility and comparability of results. J. Paleolimnol. 25, 101-110.

Jenny, H., 1941. Factors of Soil Formation. McGraw-Hill Book Company, New York.

Jin, P., 1993. The study of environmental background value of soils from Jilin Province. Jilin Geol. Sci. Technol. Information 3, 13-24.

Johnson, K., Haines, T., 2007. Controls on mercury and methylmercury deposition for two watersheds in Acadia National Park, Maine. Environ. Monit. Assess. 126, 55-67.

Juillerat, J.I., Ross, D.S., Bank, M.S., 2012. Mercury in litterfall and upper soil horizons in forested ecosystems in Vermont. U. S. A. Environ. Toxicol. Chem. 31, $1720-1729$.

Låg, J., Steinnes, E., 1978. Regional distribution of mercury in humus layers of Norwegian forest soils. Acta Agr Scand. 28, 393-396.

Larssen, T., de Wit, H., Wiker, M., Halse, K., 2008. Mercury budget of a small forested boreal catchment in southeast Norway. Sci. Total Environ. 404, 290-296. http:// dx.doi.org/10.1016/j.scitotenv.2008.03.013.

Li, B., Shi, J.B., Wang, X., Meng, M., Huang, L., Qi, X.L., He, B., Ye, Z.H., 2013. Variations and constancy of mercury and methylmercury accumulation in rice grown at contaminated paddy field sites in three Provinces of China. Environ. Pollut. 181, 91-97.

Lin, Y., Vogt, R., Larssen, T., 2012. Environmental mercury in China: a review. Environ. Toxicol. Chem. 31, 2431-2444.

Liu, R.H., Wang, Q.C., Lu, X.G., Fang, F.M., Wang, Y., 2003. Distribution and speciation of mercury in the peat bog of Xiaoxing'an Mountain, northeastern China. Environ. Pollut. 124, 39-46.

Luo, Y., Duan, L., Wang, L., Xu, G., Wang, S., Hao, J., 2014. Mercury concentrations in forest soils and stream waters in northeast and south China. Sci. Total Environ. 496, 714-720.

Ma, M., Wang, D., Sun, R., Shen, Y., Huang, L., 2013. Gaseous mercury emissions from subtropical forested and open field soils in a national nature reserve. southwest China. Atmos. Environ. 64, 116-123.

Mazur, M., Mitchell, C.P.J., Eckley, C.S., Eggert, S.L., Kolka, R.K., Sebestyen, S.D., Swain, E.B., 2014. Gaseous mercury fluxes from forest soils in response to forest harvesting intensity: a field manipulation experiment. Sci. Total Environ. 496, 678-687.

Mohammad, T.K.N., Khosro, M., Ali, G., Abbas, H., Mohammad, S.S., 2014. Cadmium and mercury in topsoils of Babagorogor watershed, western Iran: distribution, relationship with soil characteristics and multivariate analysis of contamination sources. Geoderma 219, 177-185.

Navrátil, T., Shanley, J., Rohovec, J., Hojdová, M., Penížek, V., Buchtová, J., 2014. Distribution and pools of mercury in Czech forest soils. Water Air Soil Pollut 225, 1829. http://dx.doi.org/10.1007/s11270-013-1829-1.

Pena-Rodriguez, S., Pontevedra-Pombal, X., Gayoso, E.G.R., Moretto, A., Mansilla, R., Cutillas-Barreiro, L., Arias-Estevez, M., Novoa-Munoz, J.C., 2014. Mercury distribution in a toposequence of sub-Antarctic forest soils of Tierra del Fuego (Argentina) as consequence of the prevailing soil processes. Geoderma 232, $130-140$.

Prevost, M., 2004. Predicting soil properties from organic matter content following mechanical site preparation of forest soils. Soil Sci. Soc. Am. J. 68, 943-949.

Rieder, S.R., Tipping, E., Zimmermann, S., Graf-Pannatier, E., Waldner, P., Meilid, M., Frey, B., 2014. Dynamic modelling of the long term behaviour of cadmium, lead and mercury in Swiss forest soils using CHUM-AM. Sci. Total Environ. 468-469, 864-876.

Schlüter, K., 2000. Review: evaporation of mercury from soils. An integration and synthesis of current knowledge. Environ. Geol. 39, 249-271.

Schwesig, D., Ilgen, G., Matzner, E., 1999. Mercury and methylmercury in upland and wetland forest soils of a watershed in NE-Bavaria, Germany. Water Air Soil Pollut. 113, 141-154.

Schwesig, D., Matzner, E., 2000. Pools and fluxes of mercury and methylmercury in two forested catchments in Germany. Sci. Total Environ. 260, 213-223.

Selvendiran, P., Driscoll, C.T., Montesdeoca, M.R., Bushey, J.T., 2008. Inputs, storage, and transport of total and methyl mercury in two temperate forest wetlands. J. Geophys. Res. 113, G00C01. http://dx.doi.org/10.1029/2008JG000739.

Szopka, K., Karczewska, A., Kabała, C., 2011. Mercury accumulation in the surface layers of mountain soils: a case study from the Karkonosze Mountains, Poland. Chemos 83, 1507-1512.

Tabatchnick, M.D., Nogaro, G., Hammerschmidt, C.R., 2012. Potential sources of methylmercury in tree foliage. Environ. Pollut. 160, 82-87.

US EPA, 1999. Method 1631. Revision B: Mercury in Water by Oxidation, Purge and Trap, and Cold Vapor Atomic Fluorescence Spectrometry. United States Environmental Protection Agency, pp. 1-33.

Wang, S., Xing, D., Wei, Z., Jia, Y., 2013. Spatial and seasonal variations in soil and river water mercury in a boreal forest, Changbai Mountain, Northeastern China. Geoderma 206, 123-132.

Wang, Z.W., Zhang, X.S., Xiao, J.S., Ci, Z.J., Yu, P.Z., 2009. Mercury fluxes and pools in three subtropical forested catchments, southwest China. Environ. Pollut. 157, 801-808.

Yang, Y., Zhang, C., Shi, X., Lin, T., Wang, D., 2007. Effect of organic matter and pH on mercury release from soils. J. Environ. Sci. 19, 1349-1354.

Yang, Y.K., Chen, H., Wang, D.Y., 2009. Spatial and temporal distribution of gaseous elemental mercury in Chongqing, China. Environ. Monit. Assess. 156, 479-489.

Zechmeister, H.G., 1995. Correlation between altitude and heavy metal deposition in the Alps. Environ. Pollut. 89, 73-80.

Zhou, J., Feng, X., Liu, H., Zhang, H., Fu, X., Bao, Z., Wang, X., Zhang, Y., 2013. Examination of total mercury inputs by precipitation and litterfall in a remote upland forest of Southwestern China. Atmos. Environ. 81, 364-372. 